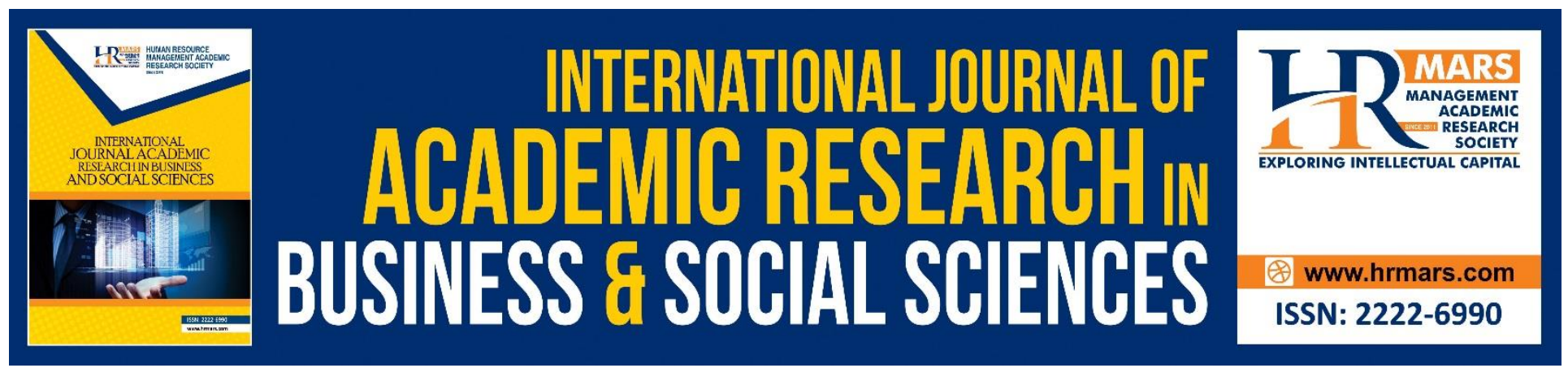

\title{
Moderating Effect of Gender and Work Experience on Information Exchange and Supply Chain Performance
}

\author{
Jones Oghenemega Ejechi, Efosa Abiodun Oshodin
}

To Link this Article: http://dx.doi.org/10.6007/IJARBSS/v9-i6/5981

DOI: $10.6007 /$ IJARBSS/v9-i6/5981

Received: 16 April 2019, Revised: 24 May 2019, Accepted: 02 June 2019

Published Online: 28 June 2019

In-Text Citation: (Ejechi \& Oshodin, 2019)

To Cite this Article: Ejechi, J., \& Oshodin, E. (2019). Moderating Effect of Gender and Work Experience on Information Exchange and Supply Chain Performance. International Journal of Academic Research in Business and Social Sciences, 9(6), 673-682.

Copyright: (C) 2019 The Author(s)

Published by Human Resource Management Academic Research Society (www.hrmars.com)

This article is published under the Creative Commons Attribution (CC BY 4.0) license. Anyone may reproduce, distribute, translate and create derivative works of this article (for both commercial and non-commercial purposes), subject to full attribution to the original publication and authors. The full terms of this license may be seen at: http://creativecommons.org/licences/by/4.0/legalcode

\section{Vol. 9, No. 6, 2019, Pg. $673-682$}

Full Terms \& Conditions of access and use can be found at http://hrmars.com/index.php/pages/detail/publication-ethics 


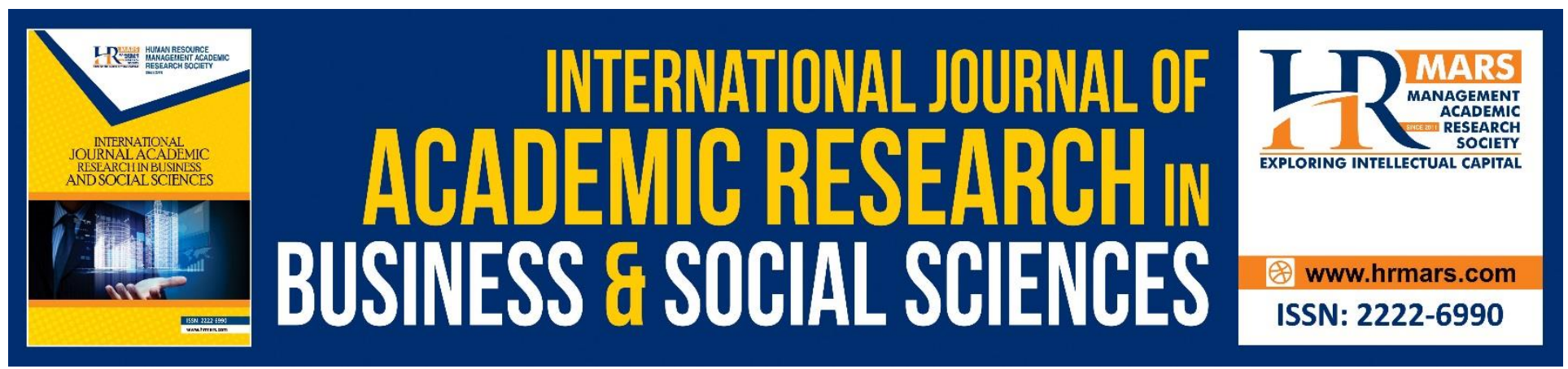

\title{
Moderating Effect of Gender and Work Experience on Information Exchange and Supply Chain Performance
}

\author{
Jones Oghenemega Ejechi, Efosa Abiodun Oshodin ${ }^{1}$ \\ Department of Business Administration, Management Sciences, University of Benin, Benin City, Nigeria \\ Email: abiodun.oshodin@uniben.edu1, jones.ejechi@uniben.edu
}

\begin{abstract}
This study attempts to examine the moderating effects of gender and employee work experience on the relationship between information exchange practices (relational competence and information technology competence) and supply chain performance in manufacturing firms in Edo state using AMOS 23.0. The study in conducting its analysis used a sample size of eighty-five. The study found that the effect of relational competence on information exchange is attributed to the male employees, while the effect of information technology competence on information exchange is attributed to the female employees. Also, the effect of information exchange on supply chain performance is largely attributed to the male employees. By implication this study found out that the impact of information exchange on supply chain performance is contributed mostly by the males. With respect to experience, our result indicated thatthe influence information exchange had on supply chain performance is as a result of the employees within the category of 11-15 years of experience.
\end{abstract}

Keywords: Information Exchange, Relational Competence, Information Technological Competence, Moderating Effects, Supply Chain Performance

\section{Introduction}

In a bid to gain competitive advantage over other companies, firms aim to produce high quality goods and services (Kirlio glu \& Cevik, 2013).Davarajh and Bright (2013) stated that making products of high quality introduces numerous complexities. In view of the above, numerous quality initiatives such as total quality management and just-in-time have been initiated by many organizations (Chandra \&Kumar, 2000). In time, competition has moved from being between individual organizations to being between effective supply networks and so more and more organizations are promoting supply chain competitiveness to attain organizational efficiency. In the twenty-first century, supply chain management (SCM) shapes a new manufacturing paradigm of organizational sustainability and competitiveness (Gunasekaran, 2004). Understanding and implementation of SCM is vital to remain competitive in the global competition and improving profitability (Ghatebi, Ramezani, \& Shiraz, 2013). Therefore, a successful SCM is a prominent tool to reduce cost of operation by eliminating all 
non-value-added activities in the flow of materials from supplier to producer (Chan \& Lee, 2005). In managing a supply chain, the flow of information is very important as it provides end-to-end visibility of the supply chain operations. With the accessibility to the right information, firms may be able to anticipate or proactively react to unexpected events that could have a detrimental effect on the supply chain performance. Poor information quality, which could be because of lack of sufficient information, inaccurate information and information delay, could also affect the information exchange both at operational and strategic level. Eventually, this could have an adverse impact on supply chain performance. Literatures have identified among other variables, relational competence (RC) and informational technology (IT) competence in investigating the relationship between information exchange and supply chain performance. This study therefore attempts to understand the moderating effect of two variables, which are gender and work experience on relational and information technology competence and in turn the moderating effects of these variable on the information exchange-supply chain performance relationship.

\section{Literature Review}

\section{Supply Chain Performance and Information Exchange}

Information exchange is the ability of a firm to effectively and efficiently share knowledge and information with all the partners of its supply chain (Wu, Yeniyurt, Kim \&Cavusgil, 2006). Supply chain management theory has clearly established that information exchange is a key component of successful supply chains and studies have provided support for the relationship between information exchange and supply chain performance (Moberg, Cutler, Gross \&Speh, 2009). Kim and Yang (2014) highlighted relationships between information exchange factors and business performance. Information exchange has a significant positive effect on the supply chain integration process (Kim \& Yang, 2014). An effective and efficient information exchange has been identified as one of the most fundamental capabilities in the supply chain process (Terjesen, Patel \& Sanders, 2012). This paper therefore attempts to take these studies further by examining the moderating effect of gender and work experience on information exchange and consequently supply chain performance.

\section{Relational Competence}

Relational competence can greatly improve the performance of supply chain (Paulraj, Chen \&Lado, 2012). In recent times, the trend of creating external links by organizations based upon information sharing has been growing (Barratt \& Oke, 2007). For communication between supply partners to be effective it must be genuine, frequent and involve personal contact (Chen and Paulraj, 2004). Relational competence involves the strengthening of the relationship among supply chain members, here, cooperation comes into play. Cooperation involves the interaction and formation of psychological connections between supply chain partners for mutual benefit (Smith, Carroll \& Ashford, 1995). The goal of cooperation is to create and coordinate processes seamlessly across the supply chain (Flynn, Huo \& Zhao, 2010). The moderating effect of gender and experience on this important determiner of supply chain performance would be examined. 
INTERNATIONAL JOURNAL OF ACADEMIC RESEARCH IN BUSINESS AND SOCIAL SCIENCES

Vol. 9, No. 6, June, 2019, E-ISSN: 2222-6990 @ 2019 HRMARS

\section{Information Technology Competence}

Information technology competence is largely recognized as an important factor in the management of supply chains as a result of the contributions it makes to information exchange (Ha, Lee, Lee \& Jung, 2013), supply chain integration (Li, Yang, Sun \&Sohal, 2009), communication between organisations and the performance of both the individual firm and the supply chain as a whole. Paulraj, Lado and Chen (2008)suggested that the sustainability a competitive advantage is possible if IT resources facilitate collaborative communication, leading to the development of complementary capabilities. Therefore, this paper aims to determine the moderating effect of gender and employee work experience on information technology.

\section{Gender and Experience}

Gender it appears to influences information sharing (information exhcange)behaviour. Findings from some studies suggest that gender may influence knowledge sharing behaviour. Taylor (2004) found that the use of information management systems was significantly influenced by gender, with men consistently reporting higher levels of usage of the emails, data mining, and so on than women. Lin (2006) found that gender moderated the effect of instrumental and expressive ties on information sharing. These studies suggest that gender influences information sharing behavior even if only indirectly.

According to Webster's dictionary experience is the knowledge or practical wisdom gotten as a result of what has been encountered, observed or undergone(Anon, 2001). Bergmann (2002) defines experience as "valuable, stored, specific knowledge that was acquired by an agent in a previous problem-solving situation" and is useful for future re-use by the agent. Both definitions show that human can gain experience.

This study would investigate the moderating effect of gender and experience on the information exchange-supply chain performance relationship in Nigerian manufacturing organizations.

\section{Methodology}

The study utilized the survey research design. It specifically adopted a survey research design that utilized questionnaires to obtain data from respondents. The population comprises of managers and supervisors at different levels in some organizations in Edo State, Nigeria and where managers and supervisors were randomly selected to form the sample size. The moderating effects of the data collected was analyzed using AMOS 23.0.

\section{Empirical Analysis and Result Description of Respondents' Bio-Data}

This section contains the descriptive analysis of the demographic information elicited from the sampled respondents. The demographic variables include: gender, experience and education qualification. 
INTERNATIONAL JOURNAL OF ACADEMIC RESEARCH IN BUSINESS AND SOCIAL SCIENCES Vol. 9, No. 6, June, 2019, E-ISSN: 2222-6990 @ 2019 HRMARS

Table 4.1: Respondents Demographics

\begin{tabular}{|c|c|c|c|}
\hline $\mathrm{S} / \mathrm{N}$ & Variables & & Frequency/Percentage \\
\hline \multirow[b]{2}{*}{1} & \multirow{2}{*}{ Gender } & Male & $62(75.6 \%)$ \\
\hline & & Female & $20(24.4 \%)$ \\
\hline \multirow{5}{*}{2} & \multirow{5}{*}{ Experience } & $1-5 y r s$ & $25(30.5 \%)$ \\
\hline & & $6-10 y r s$ & $40(48.8 \%)$ \\
\hline & & $11-15 y r s$ & $13(15.9 \%)$ \\
\hline & & $16-20 y r s$ & $4(4.9 \%)$ \\
\hline & & 21yrs and above & $\mathrm{Nil}$ \\
\hline \multirow{4}{*}{3} & \multirow{4}{*}{ Education } & Secondary & Nil \\
\hline & & OND & $6(7.3 \%)$ \\
\hline & & HND/BSC & $51(62.2 \%)$ \\
\hline & & $\mathrm{MSc} / \mathrm{PhD}$ & $20(24.4 \%)$ \\
\hline
\end{tabular}

Source: Researchers' computation (2019)

\section{Gender of Respondents:}

Table 4.1 showed gender distribution of respondents. It revealed that62(75.6\%) of respondent were male, while $20(24.4 \%)$ were female. This shows that more of the respondents were male

\section{Experience of Respondents}

Table 4.1 revealed that 40(48.8\%) respondents have spent between 6 to 10 years in the organization, $25(30.5 \%)$ of the respondents have spent 1 to 5 years in the organization, $13(15.9 \%)$ of the respondents have spent 11-15years in the organization, while $4(4.9 \%)$ of the respondents have spent 16-20years in the organization. This report indicates that most respondents with experiences have spent between 6 to 10 years in the organization. Also, the report further showed that none of the respondents have spent 20 years and above in the organization.

\section{Tests for Moderating Effects}

In testing for moderating effects, gender and experience of the respondents was considered.

\section{Moderating Effects for Gender}

Firstly, our analysis report on gender showed (see Table 4.2) that with respect to relational competence, the males $(p<0.01)$ had significant impact on information exchange. This implies that the males tend to share information more including on product designs and production plans than the females. On the contrary, females tend to be more open to acceptance to new forms of information technology sharing. This is shown in the result that with respect to ITC both male $(p<0.05)$ and female $(p<0.01)$ have significant impact on information exchange but the female has a higher impact. Also, with respect to supply chain performance, our study found out that males $(p<0.01)$ had more impact than females ( $p>0.05$ ). That is to say, the males generally do exchange information to enhance organizational performance than the females. 
INTERNATIONAL JOURNAL OF ACADEMIC RESEARCH IN BUSINESS AND SOCIAL SCIENCES Vol. 9, No. 6, June, 2019, E-ISSN: 2222-6990 @ 2019 HRMARS

Table 4.2: Comparison of Path Coefficients and T-values for Gender

\begin{tabular}{|l|l|lc|lc|c|}
\hline Hypothesis & \multicolumn{2}{c}{ Paths } & \multicolumn{3}{c|}{ Male } & \multicolumn{3}{c|}{ Comparison } \\
\hline H1 & RC-IE & 6.576 & $* *$ & .000 .493 & T-value & M $>\mathrm{F}$ \\
\hline H2 & ITC-IE & 2.412 .016 & & 3.828 & $* *$ & $\mathrm{M}<\mathrm{F}$ \\
\hline H3 & IE-SCP & $2.741 .006 *$ & & -.704 & .482 & $\mathrm{M}>\mathrm{F}$ \\
\hline
\end{tabular}

$* * \mathrm{P}<0.001, * \mathrm{p}<0.05 \mathrm{M}<\mathrm{F}$ means female has more impact than male and $\mathrm{M}>\mathrm{F}$ means male has more impact on than females.

Source: Researchers' computation (2019)

Table 4.3: Goodness of Fit Statistics in Moderating Effects of Gender

\begin{tabular}{|c|c|c|c|c|}
\hline Indices & Abbreviation & $\begin{array}{l}\text { Observed } \\
\text { values }\end{array}$ & $\begin{array}{l}\text { Recommended } \\
\text { criteria }\end{array}$ & References \\
\hline Chi square & $x^{2}$ & 5.919 & pval >0.05 & $\begin{array}{l}\text { Hair, Black, Babin, } \\
\text { Anderson, and Tatham } \\
\text { (2010) }\end{array}$ \\
\hline Normed chi square & $\chi 2 / D F$ & 1.480 & $1<\chi 2 / d f<3$ & Byrne (2010) \\
\hline Goodness-of-fit index & GFI & .970 & $>0.90$ & Hu and Bentler (1999) \\
\hline Adjusted GFI & AGFI & .777 & $>0.80$ & $\begin{array}{l}\text { Jöreskog and Sörbom } \\
\text { (1993) }\end{array}$ \\
\hline Normed fit index & $\mathrm{NFI}$ & .918 & $>0.90$ & \\
\hline Comparative fit index & $\mathrm{CFI}$ & .963 & $>0.95$ & \\
\hline $\begin{array}{l}\text { Root mean square } \\
\text { error of } \\
\text { approximation }\end{array}$ & RMESA & .081 & $\begin{array}{l}<0.05 \text { good fit } \\
\quad<0.08 \\
\text { acceptable fit }\end{array}$ & \\
\hline Tucker-Lewis index & TLI & .817 & $0<\mathrm{TLI}<1$ & \\
\hline
\end{tabular}

Source: Researchers' computation (2019)

The Table 4.3 above indicates that the goodness of fit for our measurement model is sufficient. 
INTERNATIONAL JOURNAL OF ACADEMIC RESEARCH IN BUSINESS AND SOCIAL SCIENCES Vol. 9, No. 6, June, 2019, E-ISSN: 2222-6990 @ 2019 HRMARS

Table 4.4: Moderation effects indicating the covariance and correlations of male and female respondents

Covariances: (Male - Default model)

Correlations: (Male - Default model)

\begin{tabular}{|l|c|c|c|c|l|l|c|}
\hline & Estimate & S.E. & C.R. & P & & & Estimate \\
\hline ZRC <--> ZITC & .353 & .130 & 2.707 & .007 & & ZRC <--> ZITC & .358 \\
\hline
\end{tabular}

Covariances: (Female - Default model)

Correlations: (Female - Default model)

\begin{tabular}{|l|c|c|c|c|l|l|c|}
\hline & Estimate & S.E. & C.R. & P & & & Estimate \\
\hline ZRC <--> ZITC & .238 & .222 & 1.072 & .284 & & ZRC <--> ZITC & .250 \\
\hline
\end{tabular}

Source: Researchers' computation (2019)

For covariance, the only covaried variables ITC-RC are found to be significant $(p<0.05)$ even though they have a low positive correlation (0.358).

\section{Moderating Effects for Experience}

Our analysis report on experience shows (see Table 4.5) that impact of relational competence on information exchange is attributed all respondents under each category $(p<0.01)$. The showed that there is a high significant impact on competitive advantage from all respondents. Considering information technology competence on information exchange the result showed that respondents in the category of $11-15$ years have more impact on information exchange $(p<0.05)$. Finally, result also showed that information exchange influences supply chain performance. Our analysis showed that more of this impact on supply chain partner are from employees who have 11-15 years of experience with the organization $(p<0.01)$.

Table 4.5: Comparison of path coefficients and T-values for Experience

\begin{tabular}{|c|c|c|c|c|c|c|c|c|}
\hline Hypothesis & Paths & \multicolumn{2}{|c|}{ Exp. 1-5yrs } & \multicolumn{2}{|c|}{ Exp. 6-10yrs } & \multicolumn{2}{|c|}{ Exp. 11-15yrs } & Comparison \\
\hline & & st. T-va & lue & t. & T-value & Est. & T-value & \\
\hline $\mathrm{H} 2$ & RC-IE & 3.498 & $* *$ & 3.145 & $.002 *$ & 5.467 & $* *$ & $1-5,11-15>6-10$ \\
\hline $\mathrm{H} 4$ & ITC-IE & .337 & .736 & -.582 & .561 & 2.958 & $.003 *$ & 11-15years > \\
\hline $\mathrm{H} 5$ & IE-SCP & .512 & .609 & .583 & .560 & 4.726 & $* *$ & 11-15years > \\
\hline
\end{tabular}

$* * \mathrm{P}<0.001, * \mathrm{P}<0.05$ no difference in impact between the categories of experience, 1-5years $>$ means it has more impact than other respondents in other experience category and $<11-15 y e a r s$ means respondents in this category have no impacts on OP while others respondents in other category had influence on OP.

Source: Researchers' computation (2019) 
INTERNATIONAL JOURNAL OF ACADEMIC RESEARCH IN BUSINESS AND SOCIAL SCIENCES Vol. 9, No. 6, June, 2019, E-ISSN: 2222-6990 (C) 2019 HRMARS

Table 4.6: Goodness of Fit Statistics in Moderating Effects of Experience

\begin{tabular}{|l|c|c|c|l|}
\hline Indices & Abbreviation & $\begin{array}{c}\text { Observed } \\
\text { values }\end{array}$ & $\begin{array}{c}\text { Recommended } \\
\text { criteria }\end{array}$ & \multicolumn{1}{|c|}{ References } \\
\hline Chi square & $\chi 2$ & 3.255 & pval $>0.05$ & $\begin{array}{l}\text { Hair, Black, Babin, } \\
\text { Anderson, and Tatham } \\
(2010)\end{array}$ \\
\hline Normed chi square & $\chi 2 / \mathrm{DF}$ & .362 & $1<\chi 2 / \mathrm{df}<3$ & Byrne (2010) \\
\hline $\begin{array}{l}\text { Goodness-of-fit } \\
\text { index }\end{array}$ & $\mathrm{GFI}$ & .983 & $>0.90$ & Hu and Bentler (1999) \\
\hline Adjusted GFI & $\mathrm{AGFI}$ & .915 & $>0.80$ & $\begin{array}{l}\text { Jöreskog and Sörbom } \\
(1993)\end{array}$ \\
\hline Normed fit index & $\mathrm{NFI}$ & .945 & $>0.90$ & \\
\hline $\begin{array}{l}\text { Comparative fit } \\
\text { index }\end{array}$ & $\mathrm{CFI}$ & 1.000 & $>0.95$ & \\
\hline $\begin{array}{l}\text { Root mean square } \\
\text { error of } \\
\text { approximation }\end{array}$ & $\mathrm{RMESA}$ & .001 & $\begin{array}{c}<0.05 \text { good fit } \\
<0.08\end{array}$ & \\
\hline Tucker-Lewis index & TLI & 0.990 & $0<\mathrm{TLI}<1$ & \\
\hline
\end{tabular}

Source: Researchers' computation (2019)

The Table 4.6above indicates that the goodness of fit for our measurement model is sufficient. Below is the table showing both the covariance and the correlation of respondents with respect to experience

Table 7: Moderation effects indicating the covariance and correlations of respondents with various categories of experience

Covariances: (Exp 1-5 - Default model)

Correlations: (Exp 1-5 - Default model)

\begin{tabular}{|l|l|l|l|l|l|l|l|}
\hline & Estimate & S.E. & C.R. & P & & & Estimate \\
\hline ZRC<-->ZITC & .350 & .204 & 1.714 & .086 & & ZRC<-->ZITC & .364 \\
\hline
\end{tabular}

Covariances: (Exp6-10 - Default model)

Correlations: (Exp6-10 - Default model)

\begin{tabular}{|l|l|l|l|l|l|l|c|}
\hline & Estimate & S.E. & C.R. & P & & & Estimate \\
\hline ZRC<-->ZITC & .157 & .155 & 1.011 & .312 & & ZRC<-->ZITC & .161 \\
\hline
\end{tabular}

Covariances: (Exp11-15 - Default model) Correlations: (Exp11-15 - Default model)

\begin{tabular}{|l|l|l|l|l|l|l|l|}
\hline & Estimate & S.E. & C.R. & P & & & Estimate \\
\hline ZRC<-->ZITC & -.140 & .229 & -.611 & .541 & & ZRC<-->ZITC & -.148 \\
\hline
\end{tabular}


INTERNATIONAL JOURNAL OF ACADEMIC RESEARCH IN BUSINESS AND SOCIAL SCIENCES

Vol. 9, No. 6, June, 2019, E-ISSN: 2222-6990 @ 2019 HRMARS

Source: Researchers' computation (2019)

For covariance, the covaried variables ITC-RC are found to be significant $(p<0.05)$ and the correlation are low (0.364).

\section{Discussion of Findings}

The result from the moderating effects of gender showed that the effect of relational competence on information exchange is attributed to the male employees, while the effect of information technology competence on information exchange is attributed to the female employees. Also, the effects of information exchange on supply chain performance is largely attributed to the male employees. By implication this study found out that the impact of information exchange on supply chain performance is contributed mostly by the male employees. Well, reason for this might be the gender distribution in the organization or some other factors.

\section{Conclusion}

This paper provides empirical justification for a frameworkthat showed the moderating effect of gender and work experience on information exchange and supply chain performance. It was concluded that relational competence affects information exchange, and this was mainly attributed to the male employees, while the effect of information technology competence on information exchange was attributed to the female employees. Also, the effect of information exchange on supply chain performance was again largely attributed to the male employees. By implication, this study found out that the impact of information exchange on supply chain performance was contributed mostly by the males. With respect to experience, our result indicated that the influence information exchange had on supply chain performance is as a result of the employees within the category of 1115 years of experience.

\section{References}

Anon. (2001). Random House Webster's unabridged dictionary. New York: Random House.

Barratt, M. \& Oke, A. (2007). Antecedents of supply chain visibility in retail supply chains:

a resource-based theory perspective.Journal of Operations Management, 25(6), 1217-1233.

Bergmann, R. (2002). Experience management: foundations, development methodology and internet-based applications. Berlin: Springer.

Byrne, B. (2010). Structural Equation Modeling with AMOS. Routledge, Taylor \& Francis Group, New York.

Chan, C. K., \& Lee, H. W. (2005). Successful Strategies in Supply Chain Management. Hershey, PA: Idea Group

Chandra, K., \& S. Kumar. (2000). Supply chain management in theory and practice: a passing fad or a fundamental change?.Industrial Management \& Data System,100 (3): 100-113.

Chen, I. J. \&Paulraj, A. (2004). Towards a theory of supply chain management: the constructs and measurements. Journal of Operations Management, 22(2), 119-150.

Davarajh, S., \& G. Bright (2013). Advanced quality management system for product families in mass customization and reconfigurable manufacturing.Assembly Automation 33 (2), 127-138.

Flynn, B. B., Huo, B. \& Zhao, X. (2010). The impact of supply chain integration on performance: 
INTERNATIONAL JOURNAL OF ACADEMIC RESEARCH IN BUSINESS AND SOCIAL SCIENCES Vol. 9, No. 6, June, 2019, E-ISSN: 2222-6990 @ 2019 HRMARS

A contingency and configuration approach.Journal of Operations Management, 28(1),58-71.

Ghatebi, M., E. Ramezani, \& Shiraz, M. A. E. (2013). Impact of supply chain management practices on competitive advantage in manufacturing companies of Khuzestan province. Interdisciplinary Journal of Contemporary Research in Business 5 (6), 269-274.

Gunasekaran, A. (2004). Supply chain management: theory and applications. European Journal of Operational Research, 159 (2), 265-268.

Kim, C. \& Yang, L. (2014). An empirical study on the causal relation of information exchange, supply chain integration process and customer satisfaction in China company.Journal of Korean Distribution and Management, 17(6), 95-106.

Kirlio glu, H., \& Z. Cevik. (2013). Measuring and reporting cost of quality in a Turkish manufacturing company: a case study in electric industry. Journal of Economic and Social Studies 3 (2), 87-100.

Li, G., Yang, H., Sun, L. \& Sohal, A. S. (2009). The impact of IT implementation on supply chain integration and performance.Int. J. Production Economics, 120, 125-138.

Lin, C. P. (2006). Gender differs: Modeling knowledge sharing from a perspective of social network ties. Asian Journal of Social Psychology 9(3), 236-241.

Ha, D., Lee, Y., Lee, S. \& Jung, J. (2013). Factors affecting information exchange of paprika farms to apply scm.Journal of the Korean Society of Supply Chain Management, 13(1), 77-86.

Hair, J., Black, W., Babin, B., Anderson, R., \& Tatham R. (2010). Multivariate Data Analysis. 7th ed. Pearson Prentice Hall, UpperSaddle River.

Hu, L., \& Bentler, P. (1999) Cutoff criteria for fit indexes in covariance structure analysis: conventional criteria versus new alternatives. StructEqu Model: Multidiscip J. 6(1),1-55

Joreskog, K., \& Sorbom, D. (1993). LISREL 8. Scientific Software International, Chicago.

Moberg, C. R., Cutler, B. D., Gross, A. \& Speh, T. W. (2009). Identifying antecedents of information exchange within supply chain.International Journal of Physical Distribution \& Logistics Management, 32(9),755-770.

Paulraj, A., Lado, A. A. \& Chen, I. J. (2012). Inter-organizational communication as a relational competency: antecedents and performance outcomes in collaborative buyer-supplier relationships.Journal of Operations Management, 26(1), 45-64.

Smith, K. G., Carroll, S. J. \& Ashford, S. J. (1995). Intra- and interorganizational cooperation: toward a research agenda. Academy of Management Journal, 38(1), 7-23.

Taylor, W. A. (2004). Computer-mediated knowledge sharing and individual user differences: An exploratory study. European Journal of Information Systems, 13(1), 52-64.

Terjesen, S., Patel. P. C. \& Sanders, N. R., (2012). Managing differentiation-integration duality in supply chain integration. Decision Sciences, 43(2), 303-339.

Wu, F., Yeniyurt, S., Kim, D. \&Cavusgil, T. (2006). The impact of information technology on supply chain capabilities and firm performance: a resource-based view. Industrial Marketing Management, 35, 493-504. 